Article

\title{
Wasatiyya Discourse in Shi'i Islam: Ayatollah Montazeri and Human Rights Jurisprudence
}

\author{
Naser Ghobadzadeh
}

check for updates

Citation: Ghobadzadeh, Naser. 2022. Wasatiyya Discourse in Shi'i Islam: Ayatollah Montazeri and Human Rights Jurisprudence. Religions 13: 126. https://doi.org/10.3390/ rel13020126

Academic Editor: Hussam S. Timani

Received: 22 November 2021

Accepted: 19 January 2022

Published: 28 January 2022

Publisher's Note: MDPI stays neutral with regard to jurisdictional claims in published maps and institutional affiliations.

Copyright: (C) 2022 by the author. Licensee MDPI, Basel, Switzerland. This article is an open access article distributed under the terms and conditions of the Creative Commons Attribution (CC BY) license (https:// creativecommons.org/licenses/by/ $4.0 /)$.
School of Arts, Australian Catholic University, Melbourne 3065, Australia; Naser.Ghobadzadeh@acu.edu.au

\begin{abstract}
There are significant differences of opinion about the successes and failures of Iran's clerical government, but it can hardly be disputed that the experience has led to the flourishing of Shī $\overline{1}$ political thought. In the past four decades, aided by government support, extensive literature has been produced endorsing the political theology of "governmental Shī ism" conceptualized by Khomeini in the early 1970s. Numerous other schools of thought have also emerged in opposition to the militant $S^{-} \overline{1}_{1} \overline{1}$ interpretation of religion by governmental Shî̀ ism. Using the concept of Wasatiyyah to conceptualize the most important counter-discourse to governmental Shī ism, this article addresses the life and thought of Ayatollah Montazeri, one of the most prominent Wasatiyyah thinkers. Focusing on the issue of human rights in Montazeri's thought, the article seeks to demonstrate how Montazeri instigated a fundamental reform of the seminary episteme, and by doing so articulated intra-religious reasoning in favor of the promotion of modern concepts such as human rights.
\end{abstract}

Keywords: Iran; Montazeri; governmental Shī ism; Khomeini; religious episteme; human rights jurisprudence

\section{Introduction}

Due to the sect's lack of proximity to governance, the political thought of Twelver Shic ism remained largely unchanged for more than a millennium. However, in the last decades of the twentieth century, for the first time since the early centuries of Islam, ${ }^{1}$ a group of Shî̀ clerics gained power in Iran, an experience that led to a flourishing of $\operatorname{Sh}^{-} \overline{1}$ political thought. The breadth of the influence of Ayatollah Khomeini's thought, as well as its receipt of government support, led to the emergence of countless thinkers whose intellectual project is to promote governmental Shī ism. ${ }^{2}$ For the past four decades, many thinkers have sought to establish supportive foundations for the discourse of governmental Shî̀ ism by re-reading Shî́ $\overline{1}$ political history as well as the ideas of the scholars of antiquity and the Middle Ages. The experience of the Shî1 clerics' governance in Iran has also provoked a backlash and the emergence of a wide range of thinkers who, while challenging the religious validity of the governmental Shî ism, speak out about the destructive effects of this experience, both in the religious and political spheres. The breadth and depth of this thought is such that one can speak of the emergence of several schools of thought, ${ }^{3}$ the most well-known of which is the religious reform movement, which emerged in the mid-1980s and has played a decisive role in the political developments of Iran over the past three decades.

This article proposes that the concept of Wasatiyyah can explain the ideas of the thinkers of the Shīi-Iranian reform movement. The life and thought of Ayatollah Hossein Ali Montazeri are examined within the framework of the Wasatiyyah school of thought. This article argues that Montazeri had a unique place among the Shî́ $\overline{1}-$ Iranian Wasatiyyah thinkers. His special position is partly due to the fact that he played an influential role in Iranian politics. More importantly, Montazeri, as a marja ${ }^{c}-i$ taqlīd, accommodated progressive ideas within the seminary's episteme. Michel Foucault defines a society's episteme as the rules within which the thinking and worldview of the people of that society take 
shape. This episteme shapes the context of the discourses that can be produced in a society (Foucault 1989). The Shî' i seminary has an independent episteme that has set the rules for its thinkers for centuries. According to the seminary episteme, individuals are duty-bound human beings and a person's rights are determined based on his or her religious beliefs. For this reason, the accommodation of modern concepts such as human rights and democracy within this episteme faces significant challenges.

In this article, I demonstrate that Montazeri made fundamental changes to this episteme and was able to accommodate concepts such as human rights and democracy in Shî́1 politico-religious thought using the accepted sources and methods of scholarly work in the seminary. Firstly, I address the key elements of Khomeinism in order to demonstrate that this discourse, both in theory and in practice, can be counted among the radical discourses of the Islamic world. In the second part of the article, after explaining Montazeri's unique position among Wasatiyyah thinkers, I focus specifically on the issue of human rights in his thought. In doing so, I illustrate how Montazeri was able to promote the idea of innate human dignity regardless of religious belief, as well as defend human rights, within the episteme of the seminary.

\section{Khomeinism: Militant $\operatorname{Sh}^{-1} \mathbf{1} \mathbf{1}$ Discourse}

Khomeinism was the first and most significant modern political stream of thought in the Shî̀ 1 world. It emerged in the 1960s and has played a decisive role in the Iranian political mosaic since then. The radicalism of this discourse is evident both in its theoretical framework, i.e., the doctrine of wilayat-i faqih and in the track record of the political system of the Islamic Republic. ${ }^{4}$ The doctrine of wilāyat-i faqīh exemplifies an authoritarian reading of Shi $\overline{1}^{-1} \mathbf{i}$ political theology. According to this doctrine, the source of government legitimacy is the will of God and there is no place for popular sovereignty. The political system proposed in the doctrine of wilāyat-i faqih is based on discrimination. The position of the head of state is reserved exclusively for a jurist, and the clergy enjoy special advantages over ordinary people in other political institutions as well. Its conceptual approach is based on the duties of believers and religious scholars, an approach in which citizenship rights are immaterial. There is not even a single mention of the concept of human rights in this doctrine, which can in no way be interpreted as consistent with modern concepts such as democracy, freedom, pluralism, and tolerance.

The political structure that emerged after the 1979 revolution was not necessarily the implementation of Khomeini's doctrine. The drafting of the constitution and the establishment of modern institutions indicated that Iran's ruling clergy had complied with a number of the rules of politicking in the modern world. Principles relating to citizenship rights, as well as electoral institutions such as the parliament and the presidency, none of which were contained in Khomeini's doctrine, were incorporated into the new political structure. One may imagine that the $\operatorname{Sh}^{-1} \overline{1}$ ulema in government posts moderated their views to meet the needs of the modern world, but such a claim is inconsistent with the way that the ruling clergy have governed over the more than four decades since 1979. It is correct to say that the ruling clergy of Iran have not been strict in following religious rules: they have demonstrated pragmatism whenever needed (Tamadonfar 2001). Khomeini went so far as to theorize the priority of political considerations over religious principles. According to him, if the interests of government demand it, the ruling faqih has the right to suspend or even violate the fundamental principles of religion. This jurisprudential innovation of Khomeini has been conceptualized as the expedient jurisprudence (Hajjarian 2001, pp. 91-122; Ghobadzadeh 2014, pp. 78-84). These flexibilities cannot be considered as signs of moderation. In fact, the purpose of these flexibilities is to expand the clergy's capacity to advance its own authoritarian policies and to more effectively constrain citizenship rights.

The ruling clergy have also formulated a harsh and highly discriminatory interpretation of the sharîa, and force all citizens to comply with this reading through the coercive measures of the state apparatus. On the basis of this interpretation, many discriminatory laws have been enacted that grossly violate women's rights. The ruling clergy have a 
similarly indefensible record on the rights of religious minorities, including those of Sunnī Muslims. Compared to other religious minorities, the situation of Bahā̄îs is much worse; they are generally disallowed from enjoying basic citizenship rights, such as the right to education and the right to work.

There can be no defense either of the performance of governmental Shî ism in terms of tolerance and moderation. In the early years after the revolution, the ruling clergy's rise to power was accompanied by their elimination of all political rivals. It only took them a few years to remove all competing groups from the political arena. This intolerance was not limited to secular groups and ideologies such as communists, liberals or nationalists; Shî̀ religious groups dissenting from governmental $\mathrm{Sh}^{-1}$ ism were also severely repressed. Over the past four decades, the Islamic Republic has also imposed many social restrictions on all Iranians. The issue of stoning and mass executions, as well as the implementation of sharîa punishments without the slightest concession, leaves no room to doubt the claim that Iran's ruling clergy have a radical and intolerant interpretation of religion. Their monopoly on true Islam has been a central claim of the ruling clergy, and terms such as "American Islam" and "English Shī ism" have been invented to invalidate other interpretations of the religion. Not surprisingly, tension and rivalry have been key features of the ruling clergy's foreign policies in relation to both Muslim and non-Muslim nations. A further feature of Khomeinism is its implacable opposition to the West. In Khomeini's discourse, not only is opposition to the West an integral component of foreign policy, but the elimination of elements of Western culture is a key goal in the cultural and social spheres as well. In sum, governmental Shī ism's reading of religion, and the manner in which it is implemented in the political, social, and international relations spheres has no place in the conceptual framework of moderate Islam. This is why concepts such as radical, extremist, violent, and hostile have been widely used to describe the political thought and behavior of Iran's ruling clergy.

\section{Backlash against Governmental $S^{-1} \mathbf{i}$ ism: $\operatorname{Sh}^{-1} \mathbf{1}$ Wasatiyyah Discourse}

A new discourse emerged in the Shî-1-Iranian world in the mid-1980s, widely referred to as religious reformism. The term Wasatiyyah can also be used to describe this discourse, as its English equivalent, moderation, is often used in the relevant literature. ${ }^{5}$ The use of the term Wasatiyyah highlights the similarities between $S^{-} \overline{1} \overline{1}$ and Sunnī reformism. At the same time, Wasatiyyah also means middle ground, and one of my key intentions in using this term is to emphasize the moderate position that Shīi-Iranian Wasatiyyah thinkers take in relation to the role of religion in the public and political spheres, a position lying between the extremes of Islamic radicalism and militant secularism.

This discourse is a direct and inverse backlash to the discourse of governmental Shî́ ism. While the clerical Islamists succeeded in expelling all their rivals from the political arena in just a few years after the 1979 revolution, new ruptures soon formed in the governmental Shî̄ discourse. As will be discussed in the following section, Montazeri was ousted in 1989 from the second most-important (after Khomeini) position in the state. After that, and with the death of Khomeini, right wing Islamists came to dominate the political arena to the extent of removing the left wing from all centers of power. This caused some religious thinkers, who had supported governmental Shī ism during the revolution and helped to institutionalize it in the early years after the revolution, to become disillusioned. Confronted by the Islamic Republic's authoritarian and repressive path, they reconsidered their views on the role of religion in the public arena. The most prominent thinkers of this movement were Abdolkarim Soroush, Mohammad Mujtahed Shabestari, Mohsen Kadivar, and Hasan Yousefi Eshkevari-to name but a few. These thinkers had close ties with the leftist political Islamists and therefore played a decisive role in the reformists' victory in the 1997 presidential election. In turn, the coming to power of the reformists created a conducive environment for this group of scholars, providing them with broader and more effective platforms to promote their ideas. With the support of Khatami's reformist government, the granting of newspaper and magazine publication 
licenses increased sharply, and a significant proportion of the content of the resultant publication boom comprised religious reformist ideas. The open political atmosphere also made it possible for reformists to give public lectures and air reformist debates in the classroom. The seminary was not unaffected by this atmosphere. A significant number of religious intellectuals were educated in and retained close ties to the seminary, and spread moderate ideas through this forum as well. Even religious intellectuals without a such a background, in particular Abdolkarim Soroush, gained a strong presence in the seminary and, in addition to presenting numerous lectures in the seminary, held face-toface debates and exchanged written arguments with many of its thinkers. Montazeri was among the seminarians who instigated a series of live debates and written exchanges of views with Abdolkarim Soroush and other religious intellectuals. A number of religious intellectuals, including Mohsen Kadivar and Emadeddin Baghi, were among Montazeri's students and maintained close contact with him. The ideas of religious intellectuals and the open political and intellectual environment of the reform period had a profound impact on Montazeri's thought. Many of the subjects he engaged with theologically in his classes and writings after 1997 reflected the ideas of the religious intellectuals and the issues raised in the reformist atmosphere of the Khatami years.

In addition to the issue of the relationship between religion and government, which is a central concern of the Shi $1 \overline{1}$ Wasatiyyah discourse, a wide spectrum of important issues has been discussed under the umbrella of this discourse. Various aspects of human rights (women's rights, the rights of religious and ethnic minorities, children's rights), and the issues of freedom, religious pluralism, tolerance, and apostasy are among the key matters subject to reevaluation by Shîi î Wasatiyyah thinkers, who have offered modern readings of each one. In all these cases, it can be said that $\operatorname{Sh}^{-} \overline{1}$ Wasatiyyah thinkers have denounced the strictness and extremism of governmental $S^{-1} 1$ ism. In addition to traditional religious sources such as the Qur'ān, hadīths, and Shî̄ì history, Wasatiyyah thinkers have also made use of various intellectual and philosophical schools of thought in the Western world in their attempts to challenge governmental Shî ism. In their work, they have highlighted the commonalities and potential for cooperation and rapprochement between the two civilizations of Islam and the West.

The readings that the Wasatiyyah thinkers have articulated in relation to the aforementioned matters shift from a focus on the apparent meaning of Qur'ānic verses and hadìths towards an emphasis on the intent and purpose of religion. According to their interpretation, human dignity, regardless of religious affiliation, is of fundamental importance. Unlike militant secularism, the Shî 1 i Wasatiyyah school does not deny the role of religion in the public and political arenas, but sees the purpose of religion in the public and political spheres as promoting social justice and ending discrimination. Tolerance and moderation are among the important elements that have been conceptualized in the debates of the $\operatorname{Sh}^{-} \overline{1}$ Wasatiyyah thinkers. The discourse provides an interpretation of religion that takes the challenges of contemporary society into account and meets the needs of Muslims in the modern world.

While all Wasatiyyah thinkers share the aforementioned goals and aspire to the same broad outcomes, there is also considerable diversity among them. These Shi $\overline{1} \overline{1}$ thinkers can be categorized in various different ways. In addition to scholars trained in the seminary, a significant number of Shī $\overline{1}$ Wasatiyyah thinkers are lay scholars who have studied in universities and hold specializations in a range of disciplines, often the modern humanities. Another sub-group of these thinkers have both seminary experience and an academic specialization. Their fields of study often have a determining impact on the types of topics they choose and the resources they use in their discussions. The main areas of university scholarship Wasatiyyah thinkers have engaged in are philosophy, political science, theology, law, history, and sociology. The degree of influence and the audience of Wasatiyyah thinkers also varies according to their expertise. The vast majority of the influence wielded by these thinkers is on the educated middle class. 
Generally, seminary study produces a sort of religious authority, and the main goals of people who study in the seminary are to don clerical robes and to take on the role of a religious leader. Individuals who have studied in the seminary perform religious rites and can earn a living in this way. However, there have always been some who, after completing their seminary study, have not sought a clerical occupation, and in some cases have become staunch opponents of the clergy and even religion. Ahmad Kasravi and Ali Akbar Hakamizadeh are among the most well-known individuals in this regard; both challenged the authority of the clergy after leaving the seminary. ${ }^{6}$ This phenomenon was relatively uncommon before the 1979 revolution, but today there are many scholars with a seminary education who have not chosen the clerical profession for various reasons. Disillusionment with governmental Shi ism and the associated loss of face of the clergy is one of the key reasons for the spread of this phenomenon. Growing criticism of the clergy making money from religion has also been a contributing factor (Soroush 1995a, 1995b). Many contemporary Wasatiyyah thinkers have not chosen the clerical profession, despite their seminary study and qualification to undertake ijtihād independently, with some casting their clerical robes aside as well. Mohammad Mojtahed Shabestari, Mustafa Malkiyan, Hasan Yousefi Eshkevari, Hadi Qabel, and Abolghasem Fanaei can be cited in this regard. In addition to eschewing the clerical robes and profession, the content of the scholarly work these scholars produce also takes a different form from that of traditional jurisprudence. In their works, references to extra-religious sources, especially the philosophical and theoretical debates of Western thinkers, are so numerous that it can be said that they think within a Western and modern episteme rather than within the epistemological framework of the Shîi seminary. That is why they have been able to communicate with the educated middle class-for whom jurisprudential and intrareligious arguments are insufficiently convincing. Of course, in enjoying this benefit, such thinkers forfeit their capacity to take on a traditional clerical role, and thus they do not possess the religious authority that a cleric operating within the traditional framework enjoys. Their extra-jurisprudential episteme means the loss of the obedience of habitual believers. Such habitual believers usually comprise the less-literate sections of society, those who still practice their religious beliefs and rites within the framework of emulation, ${ }^{7}$ i.e., that they consider following the opinions and fatwas of a senior cleric to be a religious duty.

Among the Shî ī Wasatiyyah thinkers, two individuals possess special status: Ayatollah Hossein Ali Montazeri and Ayatollah Yousef Sanei. ${ }^{8}$ Both of these Wasatiyyah thinkers constructed their arguments entirely within the episteme of the Shīi seminary, played their politico-religious roles within the same framework, and never studied or taught at secular universities. Both reached the highest rank in the seminary hierarchy, that is, marja $-i$ taqli d, and for this reason held a high level of religious authority and prestige. The exceptional importance of the ideas of these two thinkers in comparison with other Wasatiyyah thinkers arises from their laying of strong foundations for the promotion of human rights, democracy, freedom, and pluralism while also maintaining unqualified loyalty to the seminary episteme. Both Montazeri and Sanei were students of Khomeini, leaders during the revolutionary struggle, and occupied senior government positions after the revolution. However, both later withdrew from the government system and focused on research and teaching religious sciences in the seminary. Sanei had lesser standing than Montazeri, both in terms of government appointments, scholarly position and degree of influence in the sociopolitical arena. Of course, this is not to deny the significance of Sanei and his thought and influence, and his works as well as the reforms he bequeathed to $\operatorname{Sh}^{-} \overline{1}$ jurisprudence is worthy of separate analysis. ${ }^{9}$ Notwithstanding, in the continuation of this article, I will examine the importance and thought of Montazeri.

\section{The Significance and Status of Montazeri}

Montazeri belonged to a generation of Shî̄î scholars who received their entire education in the traditional jurisprudential context, who never studied at schools or universitieswhich are modern phenomena in the Shî̄ $\mathbf{i}-$ Iranian world. He was born in 1922 in Najafabad 
in central-west Iran, and entered the seminary at the age of 12, which remained the main platform for his scholarly and practical activities until the end of his life. Even when he was the designated successor to the Leader of the Islamic Republic (1985-1989), he was still based at the Qum seminary, and in addition to his political activity, taught at the highest level of seminary classes. In fact, it was during this period that he taught and published his most important jurisprudential-political work, the extensive Jurisprudential Foundations of the Islamic Government. ${ }^{10}$ Montazeri was one of Khomeini's oldest allies and played an important role in the promotion of Khomeini's ideas. He also had a pioneering role in identifying the potential of Khomeini's personality and ideas. Montazeri, along with Morteza Motahhari, ${ }^{11}$ persuaded Khomeini to start teaching dars-i khärij ${ }^{12}$ in the 1940 s (Montazeri 2000a, p. 193; Mo'asse-ye Tanzim va Nashr-e A'asar-e Emam 2006, pp. 96-97). Ayatollah Montazeri also played an important role in the designation of Khomeini as a marja' $i$ taqlid. Due to his political activities and his association with Khomeini, Montazeri was imprisoned and exiled many times during the Pahlavi era. ${ }^{13}$

Montazeri played a determining role in consolidating the position of the clergy in the political structure of the post-revolutionary state. Khomeini had formulated the idea of wilāyat-i faqīh in Najaf, Iraq, in January 1970, and made no mention of it between then and September 1979, a few days after the principle of wilāyat-i faqīh was approved by the Assembly of Experts for the Constitution (Ghobadzadeh Forthcoming). Therefore, although Khomeini was the architect of the theory of wilāyat-i faqīh, he had no direct role in its incorporation into the constitution of the Islamic Republic. It was Montazeri who recognized even more than Khomeini himself the potential of the idea of wilāyat-i faqin. Between the publication of the draft constitution and the election of the Assembly of Experts for the Constitution in June and July 1979, Montazeri presented the most coherent proposal of wilāyat-i faqih and called for its inclusion in the constitution (Montazeri 1979; Randjbar-Daemi 2013, p. 654). He was resoundingly voted onto the Assembly of Experts for the Constitution, and became its Chair. In the Assembly of Experts, Montazeri, alongside Hassan Ayat ${ }^{14}$ and Ayatollah Beheshti, ${ }^{15}$ were the main proponents of the idea of including the principle of wilāyat-i faqīh in the constitution. It is not without reason that Montazeri, along with the two aforementioned personalities, are known as the architects of the faqi $\mathrm{i}$ centered constitution (Saffari 1993, pp. 105-12; Schwerin 2015, pp. 42-64; Siavoshi 2017; Abdo 2001, p. 15).

In addition to chairing the Assembly of Experts for the Constitution, Montazeri briefly served as the Friday Prayer Imam of Tehran and later became the Friday Prayer Imam of Qum. After these posts, his most important official position was acting as the authorized representative of Khomeini in appointing members of the Supreme Judicial Council as well as judges throughout the country. Beyond this official post, Montazeri also founded several institutions and instituted many of the important occasions of the Islamic Republic's calendar. ${ }^{16}$ The role of Montazeri was not limited to these examples, and through his public statements as well as meetings with the country's officials, played a decisive role in guiding the policies of the fledgling government of the Islamic Republic. Montazeri's influential role was not a result of his official judicial position, but rather due to the fact that he was in practice the second most powerful person in the country. It was for this reason that the Assembly of Experts of the Leadership appointed him as the successor to the Leader of the Islamic Republic in July 1985. The ruling of this Assembly of Experts referred to the fact that Montazeri "is currently accepted by the overwhelming majority of the people as the future leader, and the Assembly of Experts of the Leadership recognizes and approves this choice" (Ghasemi 2016, p. 176). As designated successor to the Leader, Montazeri gradually found himself at odds with other elements of the decision-making apparatus of the Islamic Republic. He was particularly critical of the continuation of the Iran-Iraq War (1980-1988), the treatment of political prisoners, censorship of the press, and the overall management of the country. Particularly after 1988, Montazeri made his criticisms public (Siavoshi 2017, p. 134). 
In August 1988, the People's Mujahedin Organization of Iran (PMOI), an armed opposition group to the Islamic Republic, invaded Iran with Saddam Hussein's support. Although the attack was short-lived, ending quickly in the total defeat of the PMOI, it was followed by a horrific event known as the mass execution of ideological and political prisoners or the 1988 massacre. ${ }^{17}$ On the direct orders of Khomeini, political prisoners who remained true to their beliefs were executed without trial during August and September 1988 and buried in mass graves. The government of the Islamic Republic has never officially released the number of executions that took place, but various sources have estimated the dead to number up to 6000 (Abrahamian 1999, p. 215).

It was revealed after the fact that as soon as he learned of Khomeini's decision, Montazeri tried unsuccessfully to prevent the executions. The publication of Montazeri's letters to Khomeini in relation to this matter led to the removal of his designation as successor to the Leader. Despite not posing a serious challenge to the Islamic Republic at the time, Montazeri's ousting did play a decisive role in delegitimizing governmental Shî ism. The challenges that Montazeri mounted against governmental Shí ism are internal, questioning the theoretical foundations of governmental Shî ism in the language of religion. Such challenges have greater potential to cause damage than any challenge posed by secularists or even other religious groups because they speak to the part of society that is in fact the most important and influential social base of the Shí 1 government. This is very significant because, as mentioned earlier, other Wasatiyyah thinkers in Iran are not able to connect to this segment of society. In the realm of political action, despite Montazeri's removal from all official platforms, the continuation of his influence was obvious at critical political junctures. His controversial speech on 14 November 1997 led to his house arrest for more than five years. In that speech, he warned of government interference in the seminary and the loss of its independence, and questioned the legitimacy of the Supreme Leader's status as a marja'-i taqlīd. Montazeri's remarks about Khamenei's lack of legitimacy as a marja' $i$ taqli $d$ are widely cited as one of the most important pieces of evidence against the religious legitimacy of the Supreme Leader. Towards the end of Montazeri's life, which coincided with the beginning of the Green Movement, he played a very active role in the day-to-day politics of the country and for this reason became known as the spiritual father and moral voice of the Green Movement (Dabashi 2017, p. 39; Schwerin 2015, p. 8). Montazeri's progressive fatwas have also caused great controversy, some attracting extraordinary attention. Among these was a fatwa granting Bahā îs equal rights to other citizens of the country. ${ }^{18}$ Similarly, when the government was cracking down on dissent in the aftermath of the controversial 2009 presidential election, Mohsen Kadivar made a series of requests for the guidance (istift $\vec{a}^{\prime} \bar{a} t$ ) of Montazeri, as a marjac $i$ taqli $d$, in relation to the legitimacy of the government. Without naming the Leader, the fatwas issued by Montazeri in response to these questions inferred that Khamenei, the Supreme Leader, was an oppressive leader. Susan Siavoshi writes about the importance of these fatwas:

It was in his juridical responses to Kadivar's questions that Montazeri presented his most forceful case against unjust rulers, the rights of the people to dismiss them, and the process for adjudication in case rulers resist the popular verdict. It was also in these legal rulings that he, prompted by Kadivar, more emphatically than ever emphasized the right to resist an unjust system or ruler (Siavoshi 2016, p. 45).

Montazeri's influence in day-to-day politics naturally diminished after his death in December 2009. However, more important than his role in the politics of the day is his legacy in the form of his scholarly works, which despite being progressive and compatible with the necessities of life in the modern age, are conceptualized and articulated entirely within the framework of the episteme of the Shî 1 i seminary. There are few references in his writings to Western thought or philosophy; his thinking reflects and refers to Qur'ānic verses and hadiths and all his arguments are presented within the conventional methodology of seminary scholarship. Montazeri's extensive works cover a range of topics, and cannot all be examined, even summarily, in the space of a single article. What I intend to do in 
the remainder of this article is to examine the concepts of human rights in Montazeri's thought. By focusing on this topic, I want to show that Montazeri can be considered a Wasatiyyah thinker because, like Khaled Abou El Fadl (Abou El Fadl 2004, 2013), one of the prominent thinkers of the Wasatiyyah school, he emphasizes existing values in the religious tradition in order to support arguments in favor of human rights. Human rights has also been selected as an example to demonstrate how Montazeri articulated from within the episteme of the seminary a persuasive argument in support of modern concepts.

\section{The Founder of Human Rights Jurisprudence}

Throughout the lifetime of the Islamic Republic, human rights organizations have repeatedly criticized the human rights situation under Iran's Shî̄ clerics. There are ample statistics and evidence of discrimination, prosecution, and executions that call into question the claims of the ruling clergy that the reports are produced for political reasons. A significant proportion of these reports detail human rights abuses by the Iranian government. Perhaps the most serious evidence of human rights violations in Iran is government law, which institutionalizes persecution in the country's legal, judicial, and political systems. The roots and justification of this discriminatory structure can be traced to a key feature of Shî́ $\overline{1}$ jurisprudence according to which human beings are classified based on their beliefs. The main factors differentiating between individuals are gender, religious belief, and the level of a person's religious knowledge and piety (Kadivar 2015, p. 225). In Shīi jurisprudence, there are significant dissimilarities between men and women. Shî̀ jurisprudence also enshrines substantial differences between Muslims and non-Muslims, and even between Shī as and Sunnīs. The laws for non-Muslims include a subsidiary mechanism of discrimination; the jurisprudential rules that apply to the People of the Book are different from those applied to individuals with other or no religious beliefs. The situation of a person who changes his or her religious beliefs and abandons Islam is a controversial issue, but generally jurists ${ }^{19}$ believe that shedding the blood of such a person is permissible.

Therefore, the root of human rights issues in the Islamic Republic of Iran lies in the way Shî̀ $\overline{1}$ jurisprudence views human beings. In Shî̀ jurisprudence, a human's rights are not separate from his or her beliefs. However, Montazeri's thought separated a human's rights from his or her beliefs, considering human beings bestowed with inherent dignity and rights purely due to their humanity. Needless to say, this statement is not new, neither in the world nor in the Shî $\overline{1}-$ Iranian context. From an extra-religious point of view, one might even criticize Montazeri for his long delay in expressing this simple and self-evident point. Yet it must be taken into account that Montazeri lived and thought in a traditional context that has a history of more than a thousand years. The novelty and boldness of Montazeri's work, and the value and importance of his conceptualization of human rights, was that he located all his arguments in defense of the dignity and innate rights of humanity within the episteme of the seminary, using the accepted methods of jurisprudential research.

In addition to the Shî̀ $\overline{1}$ sacred texts (the Qur ān and hadīths), ${ }^{20}$ the seminary's episteme is dominated by the opinions and writings of precedent Shīi scholars, and it can even be said that their writings play a more important and decisive role than the Qur'ān and hadiths. Of course, one could argue that the writings of the renowned scholars are also based on the Qur'ān and hadìths, and therefore their more prominent role in the episteme of the seminary does not negate the preeminence of the Qur'ān and hadīths. This is true, but the problem is that the jurisprudential approach taken by the forefathers of Shî ism to understanding and interpreting the verses of the Qur'ān and the hadīths is still dominant. Referring to the opinions of one's predecessors is a dominant tradition in the seminary, and casting aside all the literature that has been produced over more than a millennium and referring directly to the Qur'ān and sunna is almost impossible. As mentioned, the views of the renowned $S_{h}^{-1} \overline{1}$ jurists are based on human inequality and human rights were irrelevant to them. Throughout the seminary's several-hundred-year history, no jurist produced a book or pamphlet under the title of human rights. Montazeri was the first Shî $\overline{1}^{-}$jurist to write a book with "human rights" in the title, thus he can be considered the 
founder of human rights jurisprudence in the episteme of the $\operatorname{Sh}^{-} \overline{1}$ seminary. Montazeri himself criticized seminary scholars' submission to their predecessors, writing that:

In the scholarly dimension, one of our most important mistakes was we did not pay attention to the human essence of human rights in our jurisprudential research, and we followed the tradition of our righteous predecessors, and considered some of the discussions about dignity and innate human rights as Western imports, while many of these issues are derived from the sharîa, some are emphasized in the [Qur ānic] verses and hadìths, some others need to be carefully researched and studied (Montazeri 2009, pp. 164-65).

Referring to many Qur'ānic verses and ḥadīths that speak of human honor and dignity, Montazeri argues that in these sacred texts, the word human is used and not the word believer, Muslim, woman, man, or jurist. Referring to the verse, "Verily we have honored the Children of Adam", ${ }^{21}$ Montazeri emphasizes that "human beings are honorable in essence, even if one is a disbeliever, because the essence of human beings is respected by God" (Montazeri quoted in Baghi 2014, p. 160). Montazeri does not consider these rights subject to the conditions of any specific time or place:

The fundamental rights of humans are not the product of a particular necessity or requirement of time and place; because such rights—such as the right to selfdetermination, the right to life, the right to a livelihood and a healthy life, the right to freedom of thought and expression, and the right to personal and social security-are first and foremost innate rights and therefore fixed, inalienable and inherent to human beings .... These rights are not rooted in legislation or the will of the government; rather, they have innate roots and are considered as axioms of practical reason (Montazeri 2015, p. 17).

Verse 13 of chapter 49 of the Qur'ān states, "The noblest of you before Allah is the most righteous of you." Separating the value of dignity from intrinsic dignity, Montazeri argues that this verse is related to value of dignity, which has no effect on human social rights, and that "all human beings, regardless of their level of faith and piety, enjoy such [social] rights" (Montazeri 2015, p. 39). Like Sunnī Wasatiyyah thinkers, Montazeri also emphasizes the need to consider the maqāsìd al-sharît $a$ (higher objectives of Islamic law). In his view, when a sharîa ruling comes into conflict with a ruling of theoretical or practical reason "it becomes clear that the true aim and perspective of the sharía is something different from the apparent content [of the sharía ruling], or that the content was limited to a specific time and place that had other requirements." (Montazeri 2015, p. 23). Montazeri also analyzes many narrations in which the Prophet and infallible Shîî Imāms forbade their followers from insulting or deriding Muslims and non-Muslims. He concludes that if insult and desecration are prohibited, then naturally the more fundamental rights of non-Muslims, such as the right to life and the right to a different opinion, are bestowed with even greater respect.

Many Muslim thinkers have been criticized for having apologetic approaches (Shavit 2017; Hughes 2015; Daneshgar 2020, pp. 15-65). In relation to the issue of human rights, the apologetic approach is even more pronounced since most discussions have focused solely on controversial issues such as the ruling on apostasy, the implementation of sharía punishments, or women's rights. Many Muslim thinkers have not been involved in human rights issues beyond these controversial issues; in contrast, Montazeri's engagement in human rights issues was expansive to the extent that he broadened the discussion of human rights to encompass social rights too. In religious sources, for example, Montazeri identified strong legal foundations for the right to a retirement pension, the right to education, the right to employment, and the right to housing. Not only did he address these issues in detail in his Treatise on Rights, but he also discussed various aspects of human rights in most of his writings, as well as in his fatwas and classes. Montazeri systematically classifies rights in five categories: (1) God's rights over humanity; (2) a human's rights over him or herself; (3) reciprocal rights of human beings in relation to each other; (4) the rights of 
nations in relation to each other; and (5) the rights of and between humanity, nature, and animals. The important point in Montazeri's arguments is that in relation to each of his numerous examples of rights, he refers to evidence from Qur'ānic verses and hadīths, and the early history of Islam, especially the words and deeds of the Prophet and Imām 'Alī, the first Shī $\overline{1}$ Imām. For example, in relation to the right to a retirement pension, he refers to a story from the rule of Imām 'Alī, writing: "His Excellence came across an old Christian man who was begging among the people, and asked about his situation. The companions said: That man is a Christian! His Excellence said: When he was young and able, you worked for him, and now that he is old and helpless, you have abandoned him in this state? And he ordered that the man be provided for from the treasury" (Montazeri 2015, p. 67). In relation to the requirement to meet the needs of the deprived and orphans, the right to work and choice of housing, and the rights of the sick and elderly, Montazeri uses similar sources, and considers the realization and observance of such rights a religious duty.

In relation to political matters, Montazeri also used religious sources to promote a democratic system. This issue is beyond the scope of this article, ${ }^{22}$ but it is worth noting that he also used human rights issues to promote elements of democratic polity. This part of his argument addresses human rights issues in detail, especially that which appears in his book Jurisprudential Foundations of the Islamic Government (Montazeri 1988). Referring to the rule of "enjoining good and forbidding evil", Montazeri argues that this directive is not limited to personal issues and "is also highly obligatory in relation to the social structures of religion and morality." He also argues that enjoining good and forbidding evil, in addition to being obligatory, is also a "universal right." He continues that the necessary conditions and facilities must be provided for the carrying out of this important religious duty. In the political arena, the conditions for enjoining good and forbidding evil are realized when citizens can gather together in the form of parties and communities, and through these political organizations, make comments about and strive to reform or change the affairs and programs of the political system. In other words, according to Montazeri, the complete and correct realization of the rule of enjoining good and forbidding evil requires freedom of expression and freedom of association (Montazeri 2000b, pp. 1031-34).

Further examples of political arguments in Montazeri's discussion of human rights are the issues of temporary detention and political prisoners. Referring to a hadith from Imām Ṣādiq, the sixth Imām, ${ }^{23}$ he states that according to the Islamic sources and sunna, temporary detention is permitted only in the case of a murder charge, and even in that case can occur only for a very limited period of time (Montazeri 2015, pp. 103-4). Montazeri also cites numerous narrations to demonstrate that torture for the purpose of obtaining a confession is not permitted by sharî $\bar{r}^{-} \mathrm{a}$, and that any trial based on such a confession would be invalid (Montazeri 2003, pp. 418-20).

As for political prisoners, Montazeri believes on principle that there should be no political prisoners. Montazeri refers to the manner in which the Prophet and Imām 'Alī dealt with their opponents and writes that until such a time as an opposition figure took up arms against the Prophet or Imām 'Alì, no action was taken against them. For this reason, Montazeri writes that in the time of the Prophet and Imām 'Alī, "there was not even a single case of a political prisoner being arrested and tried for expressing an opinion and criticizing the government" (Montazeri 2006b, p. 131). Therefore, from an Islamic perspective, the detention and trial of individuals on political charges is against sharîa law.

Montazeri also addressed the issue of freedom of religion and apostasy in detail. In general, he is opposed to the death penalty for a person who has abandoned Islam. Montazeri gives various reasons and cites multiple religious sources in reaching this view, including the fact that the Qur'ān does not prescribe the death penalty for apostates (Akbar 2021 b, p. 9). Referring to the verse, "There is no compulsion in religion," 24 he emphasizes that religion cannot be a matter of force. Montazeri does not deny the existence of hadiths that prescribe the death sentence for an apostate, nor does he fail to acknowledge that there were cases where apostates were executed in the early days of Islam. However, he draws upon intra-religious arguments to reject the death sentence for a person who converts 
from Islam. Montazeri argues that "choosing a religion or belief, or changing it, is not apostasy" (Montazeri 2008, p. 130) and that the ruling on apostasy is relevant to a person who "intends to conspire against the Islamic community" (Montazeri 2006a, p. 694). To clarify this discussion, Montazeri presents a definition of faith and disbelief: "Achieving certainty and belief in something is not a human choice; while faith and disbelief are two voluntary actions ... Faith means a practical and moral commitment to a belief that is found in the heart, and disbelief means the denial and non-adherence to that [belief]" (Montazeri 2006c, pp. 526-27). Montazeri continues that an apostate is a person who, despite their certainty in the legitimacy of Islam, "denies it out of stubbornness or bigotry, or for political, economic, or other [comparable] motives" (Montazeri 2006c, p. 527). He concludes that it is very difficult to prove apostasy, because it cannot be said with certainty that a person who outwardly denies Islam really believes in its legitimacy in their heart, and denies Islam out of stubbornness or due to other motives. Montazeri sees the use of the death penalty for apostasy in the early days of Islam not as a punishment for a change of belief, but for an intention to make an attack on Islam. In his opinion, at the time when the Muslim population was very small, converting to Islam and subsequently abandoning the religion was one of the enemies' strategies designed to damage the morale of Muslims. Therefore, in order to prevent this political tactic by his enemies, the Prophet announced that the death sentence would apply to those who left Islam. Montazeri argues that because the core of the issue has now been eliminated, and the Muslim community is so vast that one person leaving the faith cannot harm the religion, no punishment can be imposed for it (Montazeri 2006a, pp. 692-95).

Montazeri's ideas about the abovementioned issues are very close to today's human rights standards, but in relation to other human rights issues, Montazeri's views can be subject to serious criticism. Overall, Montazeri had progressive views on women's rights and issued several progressive fatwas in this regard. Part of his judicial reasoning included relating of the conditions of time and place to sharī a rulings related to women. For example, the hadith of Imam 'Alī advises, "Do not consult women because their view is weak and their determination is unstable" (Imām 'Alī b. Abī Tālib and Al-Jibouri [1009] 2009, p. 758). However, Montazeri responds that "the words of His Excellence do not impart a general rule or principle towards all women in all times and all circumstances" (Montazeri 2019, p. 458). According to Montazeri's reading, this narrative is relevant to a time and society in which women were not permitted to develop intellectually. Montazeri continues that "it has been seen and heard on multiple occasions that some women had, and have, greater reason and intellect than some men" (Montazeri 2019, p. 459). In relation to the possibility of female marāja $-i$ taqlid, Montazeri held that the key requisite of a person referred to for religious guidance is scholarly expertise, and that being a man or a woman is irrelevant to knowledge and scholarly expertise. He concluded as a result that there is no particular reason to prevent people from submitting to a female marjac $-i$ taqli $d$ for religious direction (Montazeri 2019, p. 467). Montazeri also refers to several verses from the Qur'ān indicating that men and women share the same status, and that the only feature granting superiority to a person is greater piety. Nonetheless, as Katie Manbachi (Manbachi 2013, p. 92) argues, many of Montazeri's views on key aspects of women's rights were in parallel with other prominent judicial opinions. Montazeri, for example, explicitly opposed women taking on judicial and political leadership roles. He claimed that judgeship and leadership are difficult tasks not commensurate with the physical and mental characteristics of women. He considered this religious ruling not as diminishing the status of women but recognizing their duties in proportion to their physical and mental capacities. He stated that this ruling "can be considered in fact compassionate towards and supportive of them [women]" (Montazeri 2019, p. 468). Montazeri does not address the question of whether a woman who does not desire such compassion can indeed become a judge or a political leader, or the possibility of there being women endowed with greater physical and mental strength than many men. Regarding inheritance, Montazeri defends the classical jurisprudential rule that a woman inherits half of that of a man. In defense of this view, 
Montazeri argues that throughout history, men's financial responsibilities have been greater than women's and it is for this reason that these rulings have been issued (Montazeri 2008, p. 128). Consideration of the conditions of time and place, and the more fluid financial roles of men and women in the modern world, could also be applied and effect change to these rulings. However, Montazeri did not begin to contemplate such considerations and revisions until the very end of his life. ${ }^{25}$

Although Montazeri's views on the rights of minorities are considered progressive within the seminary's episteme, they are far from the standards accepted today. In general, Montazeri argues that minorities are equal to the majority "in human rights, including public, civil, criminal, and commercial rights" (Montazeri 2008, p. 118), but in relation to senior government posts, he seeks to justify a verse from the Qur'ān prohibiting the domination of Muslims by non-Muslims. ${ }^{26}$ In Montazeri's view, in a Muslim-majority society, the minority will never gain the support of the majority to occupy a senior political post. He does not consider, for example, the jurisprudential position that should be taken if the majority voted for a non-Muslim in the presidential election. As Manbachi puts it, it seems that "Montazeri could not imagine a society where the rights of the minority were considered over the majority" (Manbachi 2013, p. 105).

At the same time, the claim that Montazeri addresses a wide range of human rights issues should not be taken to mean that he addressed all human rights issues. He avoided engagement in some controversial issues, such as the rights of homosexuals. It is difficult to imagine that he did not think about this matter at all. Perhaps he knew that there was no way to provide a moderate reading on the subject of homosexuals within the seminary episteme, and that defending these humans' rights required a complete departure from the religious context. Of course, a more robust speculation could be that Montazeri had a set of strong religious beliefs that did not necessarily conform to accepted human rights norms. This article does not argue that Montazeri's ideas were fully aligned with human rights standards or other modern concepts such as democracy and pluralism. Rather, its central claim is that Montazeri made fundamental changes to the seminary episteme from within, forging a path that is being continued and expanded by his students today. It is not unreasonable to claim that due to Montazeri's efforts, moderate readings of religion in relation to several issues have already become part of the Shî̀ $\overline{1}$ seminary episteme. Individuals such as Mohsen Kadivar, Ahmad Qabel, Mohammad Soroush Mahallati, Ayatollah Assadollah Bayat Zanjani (Ridgeon 2020, 2021; Jahanbakhsh 2020), as well as numerous others, present moderate readings of religion in relation to a range of matters.

In sum, Montazeri was not only important in terms of his statements and ideas. His position in the seminary, as well as the context in which he conceptualized his progressive ideas, was even more significant. It can be said that compared to other Shīi Wasatiyyah thinkers such as Abdul Karim Soroush, Mohsen Kadivar, and Mohammad Mojtahed Shabestari, Montazeri's views were not particularly progressive, but as a marja'-i taqlid, Montazeri enjoyed religious authority and could build relationships with the community of habitual believers. Other Wasatiyyah thinkers cannot easily approach this class. In addition to his access to the class of ordinary believers, Montazeri established a new kind of thinking within the seminary's episteme. Without the help of modern or Western philosophies, and solely within the accepted frameworks of the Shî̀ seminary, he made it possible to reconcile religiosity with modern ideas.

\section{Conclusions}

The theological foundations of political Islam, which emerged in the Shî̀ $\overline{1}$ and Sunnī worlds in the second half of the twentieth century, are fundamentally different. Khomeini's doctrine of wilāyat-i faqīh, for example, has very little in common with the politico-religious theories developed in the Sunnī world by Sayyid Qutb and Abū al-A'lā al-Mawdūdī. However, both branches of political Islam emerged in response to common concerns, and both expressed a this-worldly interpretation of religion. Further, both groups of ideologues 
claimed that religious sources could offer Muslims a better life. Therefore, returning to religious teachings comprised key elements of both discourses. As the imaginings of and depictions presented by these movements' leaders created a utopia in opposition to the ideologies of modern Western civilization, they rejected the key elements of political thought in the modern world, such as secularism, human rights, freedom, democracy, and pluralism.

A further common denominator between the Sunnī and $\operatorname{Sh}^{-} \overline{1}$ political movements was that the lived experience of each discourse led to backlashes, the most important of which was the Wasatiyya school of thought. The Wasatiyya school offers an alternative reading to political Islam which stands for the possibility of reconciling religious teachings with modern concepts such as human rights and democracy. In this article, Ayatollah Montazeri's life and thought, particularly his ideas about human rights, were analyzed as an example illustrating the Wasatiyya school of thought in the Shîi world, and it was shown that Montazeri promoted human rights within the framework of the seminary's own episteme. By challenging governmental Shî ism's radical reading of religion, he sought to show that religious teachings are consistent with modern and humane ideas. This article demonstrated that Montazeri was a pioneering marāja ${ }^{c}-\mathrm{i}$ taqlīd of the Wasatiyya school of thought in the $\operatorname{Sh}^{-} \overline{1}$ seminary, and forged a path that is being followed and reinforced by others today. Separate research is necessary to examine the extent to which Wasatiyya thinking has developed within the Shî̀ seminary.

Funding: This research received no external funding.

Institutional Review Board Statement: Not applicable.

Informed Consent Statement: Not applicable.

Data Availability Statement: Not applicable.

Acknowledgments: The author would like to thank the anonymous reviewers for their constructive comments.

Conflicts of Interest: The author declares no conflict of interest.

\section{Notes}

1 Only two of the infallible Imāms of Twelver Imāmi Shî̀ ism ruled for any period. Imām 'Alī, the first Shīi Imām, served as the fourth caliph from 656 to 661, and after he died, his son Imām Haṣan claimed the caliphate. However, after seven months, Haṣan signed a treaty handing over the caliphate to another claimant, $\mathrm{Mu}^{\prime}$ āwiya I. None of the other infallible Imāms reached the position of caliph. The Twelver Shīi clergy were never in power throughout history. Ayatollah Khomeini was the first Twelver Imāmi Shî̀ $\mathbf{1}$ religious scholar ever to head a government.

2 The term governmental Shī' ism has been proposed to describe Khomeini's innovative political theology for two reasons. First, a significant part of Khomeini's life and the development of his conceptualization is indebted to his having control over the government apparatus. More importantly, contrary to the centuries-old tradition of the Twelver Shî ism, Khomeini conceptualized a version of political theology whose central and essential element is the seizure of power by religious leaders.

3 Numerous books and articles have been written about schools of thought in the seminary of Qum. See for example (Tabatabaeifar 2015; Mousavi 2004; Forati 2016).

4 It is necessary to acknowledge here that the phenomenon of governmental Shī ism is by no means a static and integrated phenomenon. Its formation in the 1960s and 1970s took place via an evolutionary process, and it has had a checkered history since its implementation in the form of a political system. One can identify periods of flexibility as well as radicalism in the more than half a century of governmental Shī ism. However, many commentators judge the government's response to political demonstrations since 2009 or the brutal crackdown on protesters in 2019 as pivotal turning points when the possibility of governmental $\mathrm{Sh}_{\overline{1}}^{\mathrm{c}}$ ism making any compromise with the reformists died. In this article, I focus only on the key and persistent elements of governmental Shî ism. In addition, I should point out that there is a wide spectrum of ideas within the discourse of governmental Shî ism itself, and considerable intellectual differences exist between its adherents. However, the examination of the variety of governmental Shî̀ thought is beyond the scope of this article. This article focuses solely on elements of the discourse of governmental Shî ism that were not only key to Khomeini's thinking, but are points upon which all adherents agree. See for example (Tezcür 2010; Amini and Rahmani 2016; Kamali 2015; Ghobadzadeh 2018). 
$6 \quad$ Khomeini produced his first political work, Kashf al-Asrār, in response to a book written by Ali Akbar Hakamizadeh, titled Secrets of a Thousand Years and directed against religion and the clergy. Hakamizadeh withdrew from scholarly work in the face of intense pressure and worked in poultry farming until his death in 1987. Ahmad Kasravi became a staunch and active opponent of religion and the clergy after setting aside his clerical robes in 1912. For this reason, he was assassinated in March 1946 by the radical Islamist group Fadā iyān-e Islam. For a discussion of Hakamizadeh and Kasravi, see (Kia 2014; Basirat-Manesh 2016; Asil 1977; Abrahamian 1973; Ja'farian 2019; Ridgeon 2006).

7 In Shî ism, believers are categorized into two groups: a minority are mujtahids (jurists) and the remaining majority are muqallids (emulators). The former are those who possess the aptitude to form their own judgement regarding questions concerning the sharî̄a, or put simply, experts sufficiently skilled to exercise ijtihād. Ijtihād is the intellectual effort made by a jurist to derive Islamic rules based on the analysis of primary sources (Qur'ān and hadiths) through the prism of reason. In other words, the job of a mujtahid is to use his reason to derive rulings from Islamic scriptures instead of merely following to the literal, unrefined, words of the text. Muqallids, on the other hand, are lay believers and are generally considered ignorant when it comes to religious matters. They are, therefore, charged with the religious responsibility to obey and submit to the decrees issued by the mujtahids. The use of the term "emulation" makes sense here because what happens between these two groups is-in effect-the blind submission of the muqallids to the mujtahids. Some trace the history of taqlid to the time of Prophet Mohammad and the infallible Imāms (Ghorbani 2003, pp. 127-268). However, the extant evidence suggests that the conception and practice of taqlìd has been part of the Shī $\overline{1}$ scholastic discussion and religious practices from the 5th/12th centuries onward (Clarke 2001). For a concise explanation of the history and practice of taqlid, see (Najafi and Kazmi 2010; Ghorbani 2003).

8 Of course, there have been other marāja 'i taqlīd in Qum who are known as reformist marāja', including Seyed Musa Shobiri Zanjani, Asadollah Bayat Zanjani, Abdul-Karim Mousavi Ardabili and Seyyed Ali Mohammad Dastgheib. However, these marāja' are mostly known as reformists because of the proximity of their political stances and personages to reformists. They have relatively less-radical views, but it would be problematic to claim that they defend, for example, human rights, pluralism or freedom.

9 In the fields of jurisprudence and politics, Sanei presented very different views from both his predecessors and contemporary marāja '-i taqlīd. In particular, his fatwas on the equality of blood money between men and women, the lack of permissibility of temporary marriage, questioning the punishment for apostasy, giving permission to unbelievers to inherit from Muslims, and forbidding a man to take a second wife without the permission of his first caused a great deal of controversy. For a discussion of Sanei's life and thought, see (Hosseini 2011; Akbar 2021a; Mir-Hosseini 2008, pp. 219-24; Sadat Moinifar 2007; Rad Goudarzi 2021; Ebrahimnezhad 2016).

10 This book is a record of Montazeri's wilāyat-i faqīh lectures, which he taught in advanced-level seminary classes from 1985 to 1989 The book was first published as a four-volume Arabic work in Beirut and Qum. Its Persian translation was published in eight volumes between 1988 and 2007 in Tehran. Khomeini's book Wilāyat-i faqīh was also a record of his lectures at the Najaf seminary, presented in thirteen sessions in January and February 1970. Montazeri's discussion is much deeper and broader than that of Khomeini; Montazeri was actually the first jurist throughout the entirety of Shī $\overline{1}$ history to address the issue of wilāyat-i faqīh in detail.

11 Morteza Motahhari, one of the most important ideologues of the Islamic Republic, was assassinated less than three months after the victory of the 1979 revolution. Among the revolutionary clerics of the 1960s and 1970s, Motahhari is considered a mastermind of revolutionary Shî ism and produced the most works. For more on his life and role in the 1979 revolution, as well as his politico-religious ideas, see (Shimamoto 2006; Motahhari et al. 2000; Davari 2005).

Seminary education is comprised of three levels: introductory (muqadamāt), intermediate (sath), and advanced (dars-i khärij). Traditionally, there is no centralized structure for teaching in the seminary. A student can offer a class after several years of seminary study. The success rate of each class depends on how many students it attracts. Students are completely free to choose their classes and teacher. For a person to start teaching at a given level requires at least a few students to have expressed interest in attending his or her class first. It often happens that someone establishes a class with a few students, but as a result of failing to attract more attendees, the class does not continue. In other cases, the class begins with just a few attendees, but gradually the number of participants increases to the hundreds. The most important criterion for determining the status of a mujtahid in the seminary is the number of students in his or her classes. For further detail on the Shî $\overline{1}^{-}$seminary education system, see (Kariami et al. 2005; Shirkhani and Zareh 2005; Soleimanieh 2013).

For a more detailed discussion of the periods Montazeri spent in exile and in prison, as well as his concurrent political activities, see Siavoshi (2017), pp. 73-86.

14 Hasan Ayat was initially a member of the Toilers Party of the Iranian Nation and later a member of the central committee of the Islamic Republican Party. In addition to his membership of the Assembly of Experts for the Constitution, Hasan Ayat became a member of the first Islamic Consultative Assembly. Ervand Abrahamian considers him the mastermind of the removal of Abolhassan Banisadr from the presidency, and describes his assassination in Tehran in July 1981 by the People's Mojahedin of Iran (Abrahamian 1989, p. 221).

Mohammad Beheshti was deputy chair of the Assembly of Experts for the Constitution and head of the Supreme Court of Iran from 1980 to 1981. He was assassinated on 28 June 1981.

16 For details on these initiatives of Montazeri, see (Baghi 2014, pp. 26-30; Siavoshi 2017, pp. 120-34). 
These executions are among the most serious cases of human rights violations in the Islamic Republic; they were not even conducted in accordance with the Islamic Republic's own legislated judicial processes. For further analysis of these executions, see (Shahrooz 2007; Abrahamian 1999, pp. 209-28; Sorg 2008; Robertson 2011; Mohajer 2020).

Montazeri was previously an active critic of the Bahā' $\overline{1}$ faith, and in 1950 wrote a pamphlet titled "The Muslim-Bahā'ī Debate" against the religious beliefs of the Bahā $\overline{1}$ s. Until the end of his life, he continued to believe that the Bahā'̄is' beliefs were invalid, yet he issued an unprecedented fatwa defending their citizenship rights.

Contrary to the popular belief that all jurists advocate for the death penalty for apostates, in fact there is considerable opposition to the death penalty for apostates in both $S^{-} \overline{1} \mathbf{1}$ and Sunnī jurisprudence. For further discussion, see Baghi (2014), pp. 100-8. In Sunnī jurisprudence, hadīths are limited to the words and deeds of the Prophet of Islam. In contrast, as Twelver Shī' as also believe in the sanctity of the twelve Imāms, their words and deeds are part of the body of hadīths and considered sacred texts. For various reasons, including the fact that hadith collection began later among the Shì as, there are of course many doubts about the narration of numerous hadīths and, unlike the Sunnīs, the Shī as possess no collection of hadīths whose content is all considered authentic. For a discussion of the problems related to Shīî hadīths, see for example (Askarī and Sardarnia 2012; Rahnema 2015, pp. 91-107; Al-Khū'i 1993, pp. 25-26). Q 17:70.

For a discussion of Montazeri's political views, especially the somewhat democratic system he promoted using religious sources, see (Rahimi 2008, 2012; Abdo 2001; Baghi 2014; Kadivar 2011; Siavoshi 2016; 2017, pp. 213-26).

The relevant hadīth from Imām Șādiq reads: “The Prophet's method was such that in case of a murder charge, he would imprison the accused for six days, and if during this period the relatives of the victim did not provide any evidence to prove the charge, he would release him." Q 2:256.

Montazeri's problematic views on women's rights are not limited to these examples. For discussion of other instances, see (Manbachi 2013, pp. 92-101; Siavoshi 2017, pp. 259-63).

Q 4:141.

\section{References}

Abdo, Geneive. 2001. Re-thinking the Islamic Republic: A conversation with Ayatollah Hossein Ali Montazeri. Middle East Journal 55: 9-24.

Abou El Fadl, Khaled. 2004. Islam and the challenge of democracy. In Islam and the Challenge of Democracy: A Boston Review Book. Edited by Khaled Abou El Fadl, Joshua Cohen and Deborah Chasman. Princeton: Princeton University Press, pp. 3-46.

Abou El Fadl, Khaled. 2013. Cultivating human rights: Islamic law and the humanist imperative. In Law and Tradition in Classical Islamic thought Studies in Honor of Professor Hossein Modarressi. Edited by Michael Cook, Najam Haider, Intisar Rabb and Asma Sayeed. New York: Palgrave Macmillan, pp. 167-83.

Abrahamian, Ervand. 1973. Kasravi: The integrative nationalist of Iran. Middle Eastern Studies 9: 271-95. [CrossRef]

Abrahamian, Ervand. 1989. Radical Islam: The Iranian Mojahedin. London: I.B. Tauris.

Abrahamian, Ervand. 1999. Tortured Confessions Prisons and Public Recantations in Modern Iran. Oakland: University of California Press.

Akbar, Ali. 2021a. Ayatollah Yusuf Sanei's contribution to the discourse of women's rights. Religions 12: 535. [CrossRef]

Akbar, Ali. 2021b. Punishment for apostasy: Arguments from two traditionally trained Muslim scholars in favor of its abolition. Oxford Journal of Law and Religion 10: 71-90. [CrossRef]

Al-Khūi i, Sayyid Abulqasim. 1993. Directory of Narrators and Their Detailed Classification [لحديث ومعجم رجال الحديث و تفصيل طبقات الرواة معجم رجال]. Qum: Al-thiqafat ul-Islamiyya fi al-'alam.

Amini, Ansar, and Amir Hossein Mosaver Rahmani. 2016. Moderation Movement in Iran; Moving between Liberalism and Religious Intellectualism. Journal of Sociological Research 7: 1-9. [CrossRef]

Asil, Hojjatullah. 1977. A Survey of the Political thought of Kasravi [سبرى در اندشهُ ساسى كسروى. Tehran: AmirKabir.

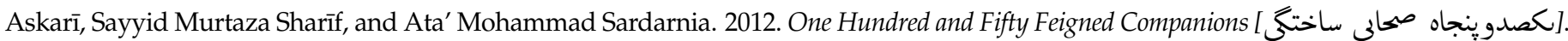
Tehran: Usul Al-din Institute of Higher Education.

Baghi, Emadeddin. 2014. Socio-Political Philosophy of Ayatollah Montazeri [فلسفه ساسى اجتماعى آتت اله منتظرى]. Tehran: Saraei.

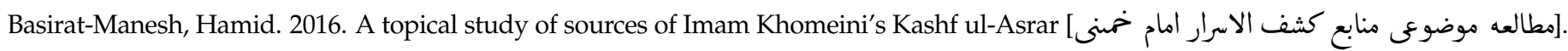
Zharfa Pazhooh 2: 1-30.

Clarke, Lynda. 2001. The Shi'i Construction of Taqlid. Journal of Islamic Studies 12: 40-64. [CrossRef]

Dabashi, Hamid. 2017. The Green Movement in Iran. London: Transaction Publishers.

Daneshgar, Majid. 2020. Studying the Qur'an in the Muslim Academy. New York: Oxford University Press.

Davari, Mahmood T. 2005. The Political thought of Ayatullah Murtaza Mutahhari: An Iranian Theoretician of the Islamic State. London: Routledge.

Ebrahimnezhad, Mohammad. 2016. A review and critique of Ayatollah Sanei's rationale for the equality of blood money for men and woman [بررسى و نقد ادله نظره آت اله صانعى در برابرى ده زن و مرد]. Jurisprudence and Islamic Law 7: 1-28. 
Forati, Abdulwahab. 2016. Intellectual and Political Typology of Clergies of Qum Seminary [ كونه شناسى فكرى ساسى حوزه علمه ق Qum: Pazhoheshgah-e Farhang va Andisheh Eslami.

Foucault, Michel. 1989. The Order of Things: An Archaeology of the Human Sciences. New York: Routledge.

Ghasemi, Fereydoun. 2016. Islamic Republic of Iran: From Bazargan to Rouhani [حهورى اسلامى ابران: از بازركان تا روحانى. London: H\&S Media.

Ghobadzadeh, Naser. 2014. Religious Secularity: A Theological Challenge to the Islamic State. New York: Oxford University Press.

Ghobadzadeh, Naser. 2018. Elections in the Islamic Republic of Iran: A source of democratic learning and moderation. Journal of Arab \& Muslim Media Research 11: 157-77.

Ghobadzadeh, Naser. Forthcoming. Theocratic Secularism vs. Governmental sh $\imath$ ism. New York: Oxford University Press.

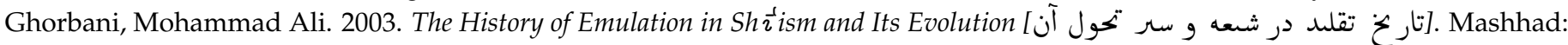
Islamic Research Foundation.

Hajjarian, Saeed. 2001. From the Sacred Witness to the Profane Witness: The Secularisation of Religion in the Sphere of Politics [از شاهد قدسى تا شاهد بازارى: عرفى شدن دن در سيهر ساست] Tehran: Tarh-e No.

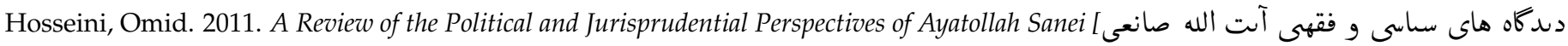
[بازخوانى. Tehran: Markaz-e Asnad-e Enqelab-e Eslami.

Hughes, Aaron W. 2015. Islam and the Tyranny of Authenticity: An Inquiry into Disciplinary Apologetics and Self-Deception. London: Equinox.

Imām 'Alī b. Ab̄̄ Tālib, and Yasin T. Al-Jibouri. 2009. Peak of Eloquence: Nahjul-Balagha. Elmhurst: Tahrike Tarsile Qur'an, Inc. First published 1009.

Ja'farian, Rasul. 2019. Ali Akbar Hakamizadeh in Four Scenes [على اكبر حكمى زاده در :حهار يرده]. Qum: Nashr-e Movarekh.

Jahanbakhsh, Forough. 2020. Rational Shari'ah: Ahmad Qabel's Reformist Approach. Religions 11: 665. [CrossRef]

Kadivar, Mohsen. 2011. The evolution of Grand Master Montazeri's political thought [سر تحول اندشه ساسى استاد منتظرى]. Mohsen Kadivar Official Website. Available online: http:/ / kadivar.com/?p=5568 (accessed on 24 June 2011).

Kadivar, Mohsen. 2015. A Tribute to the Virtuous Theologian: My Mentor HosseinAli Montazeri NajafAbadi [استاد حسنعلى متتظرى نجف آبادى : سوگنامئ فقه : Durham: Mohsen Kadivar Official Website.

Kamali, Mohammad Hashim. 2015. The Middle Path of Moderation in Islam: The Qur'anic Principle of Wasatiyyah. New York: Oxford University Press.

Kariami, Jabir, Ahmad Reza Nasr Isfahani, and Mahmud Haji Ahmadi. 2005. A comparative analysis of the education system in the seminary and university [بررسى و مقاسه نظام آموزشى حوزه و دانشعا]. Pazhoheshnam-e Tarikhi Enqilab-e Eslami 7: 11-12, 37-64.

Kia, Chad. 2014. The scum of Tabriz: Ahmad Kasravi and the impulse to reform Islam. British Journal of Middle Eastern Studies 41: 498-516. [CrossRef]

Manbachi, Katie Maryam. 2013. The Evolution of Ayatollah Montazeri's Doctrine of Velāyat-e Faqih. Master's thesis, Department of Near Eastern Studies, Princeton University, Princeton, NJ, USA.

Mir-Hosseini, Ziba. 2008. Women's right to terminate the marriage contract: The case of Iran. In The Islamic Marriage Contract. Edited by Assifa Qureishi and Frank E. Vogel. Cambridge: Harvard University Press, pp. 215-30.

Mo'asse-ye Tanzim va Nashr-e A'asar-e Emam. 2006. Imam in the narration of scholars [امام(س) به روانت دانشوران. Tehran: Mo'asse-ye Tanzim va Nashr-e A'asar-e Emam.

Mohajer, Nasser. 2020. Voices of a Massacre: Untold Stories of Life and Death in Iran, 1988. London: Oneworld Publications.

Montazeri, Hussein Ali. 1979. Ayatollah Montazeri called for the amendment of 8 articles of the constitution [قانون اساسى شل 8

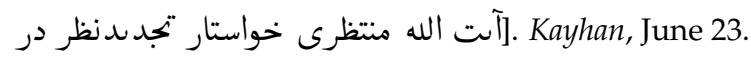

Montazeri, Hosseinali. 1988. Juriprudential Foundation of Islamic State [مبانى فقهى حكومت اسلامى. Tehran: Kayhan.

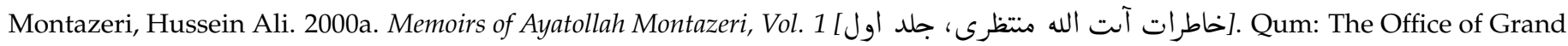
Ayatollah Montazeri.

Montazeri, Hussein Ali. 2000b. Memoirs of Ayatollah Montazeri, Vol. 2 [خاطرات آت الله منتظرى، جلد دور]. Qum: The Office of Grand Ayatollah Montazeri.

Montazeri, Hussein Ali. 2003. Perspectives I: Messages, Opinions and Interviews with Grand Ayatollah Montazeri هاى آت الله العظمى منتظرى . دuدكاهها جلد اول: يامها، نظرات و مصاحبه. Qum: The Office of the Grand Ayatollah Montazeri, vol. 1.

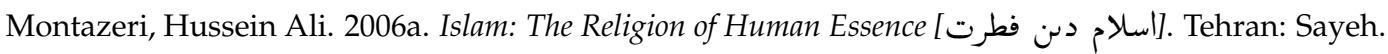

Montazeri, Hussein Ali. 2006b. Perspectives II: Messages, Opinion and Interviews of Grand Ayatollah Montazeri هاى آت الله العظمى منتظرى [دسكاهها جلد دور: يامها، نظرات و مصاحبه. Qum: The office of Grand Ayatollah Montazeri, vol. 1.

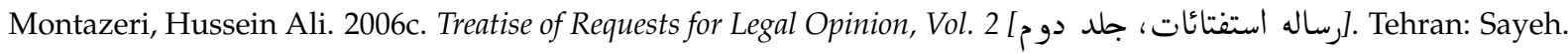

Montazeri, Hussein Ali. 2008. Religious State and Humans Rights [حكومت دننى و حقوق انسانهات دوم). Tehran: Saraie. 
Montazeri, Hussein Ali. 2009. Self-Criticism: A Salutatory Lesson and Testament [انتقاد از خود: عبرت و وصلت]. Qum: The Office of Grand Ayatollah Montazeri.

Montazeri, Hussein Ali. 2015. Treatise on Rights [رساله حقوق]. Tehran: Saraie.

Montazeri, Hussein Ali. 2019. Response to Religious Questions. vol 1 [وساسخ به يرسش هاى دنى، جلد اول. Qum: The Office of Grand Ayatollah Montazeri.

Motahhari, Morteza, Farhad Arshad, and Hamid Dabashi. 2000. The fundamental problem in the clerical establishment. In The Most Learned of the Shi'a: The Institution of the Marja'i Taqlid. Edited by Linda S. Walbridge. New York: Oxford University Press, pp. 161-82.

Mousavi, Seyed Mohammad. 2004. Doctrine and Thought: An Analysis of the Fundamentals and Perspectives of the Tafkiki School [آئن و اندشه ، بررسى مبانى و دuدكاههاى مكتب تفكع Thehran: Hekmat.

Najafi, Syed Ibne Hasan, and Syed Saeed Haider Kazmi. 2010. Taqleed E Ijtihad. Islamabad: Markaz Fikr-e-Islami.

Rad Goudarzi, Masoumeh. 2021. The equality of blood money for men and women: Ayatollah Saanei's novel hermeneutic in gender equality in shiite Islam. Women $\mathcal{E}$ Criminal Justice 31: 1-16.

Rahimi, Babak. 2008. The Discourse of Democracy in Shi'i Islamic Jurisprudence: The Two Cases of Montazeri and Sistani. Florence: European University Institute.

Rahimi, Babak. 2012. Democratic authority, public Islam, and shi'i jurisprudence in Iran and Iraq: Hussain Ali Montazeri and Ali Sistani. International Political Science Review 33: 193-208. [CrossRef]

Rahnema, Ali. 2015. Shi'i Reformation in Iran: The Life and Theology of Shari'at Sangelaji. New York: Routledge.

Randjbar-Daemi, Siavush. 2013. Building the Islamic state: The draft Constitution of 1979 reconsidered. Iranian Studies 46: 641-63. [CrossRef]

Ridgeon, Lloyd V. J. 2006. Sufi Castigator: Ahmad Kasravi and Iranian Mystical Tradition. London: Routledge.

Ridgeon, Lloyd. 2020. Ahmad Qabil, a reason to believe and the New Religious Thinking in Iran. Middle Eastern Studies 56: 1-15. [CrossRef]

Ridgeon, Lloyd. 2021. Hijab: Three Modern Iranian Seminarian Perspectives. London: Haus Publishing.

Robertson, Geoffrey. 2011. The Massacre of Political Prisoners in Iran, 1988. Washington, DC: Abdorraham Boroumand Foundation. Available online: https:/ / www.iranrights.org//attachments/library/doc_118.pdf (accessed on 18 July 2018).

Sadat Moinifar, Heshmat. 2007. Religious leaders and family planning in Iran. Iran and the Caucasus 11: 299-313. [CrossRef]

Saffari, Said. 1993. The legitimation of the clergy's right to rule in the Iranian Constitution of 1979. British Journal of Middle Eastern Studies 20: 64-82. [CrossRef]

Schwerin, Ulrich von. 2015. The Dissident Mullah: Ayatollah Montazeri and the Struggle for Reform in Revolutionary Iran. New York: I.B.Tauris.

Shahrooz, Kaveh. 2007. With Revolutionary Rage and Rancor: Preliminary Report on the 1988 Massacre of Iran's Political Prisoners. Harvard Human Rights Journal 20: 227-62.

Shavit, Uriya. 2017. Scientific and Political Freedom in Islam: A Critical Reading of the Modernist-Apologetic School. London: Routledge.

Shimamoto, Takamitsu. 2006. Leadership in Twelver Imami Shi'ism: Mortaza Motahhari's Ideas on the Imamate and the Role of Religious Scholars. Journal of the Interdisciplinary Study of Monotheistic Religions 2: 37-57.

Shirkhani, Ali, and Abbas Zareh. 2005. Transformations in the Qum Seminary after the Victory of the Islamic Revolution يروزى انقلاب اسلامى تخولات حوزه علمه قُ : يس از Tehran: Markaz-e Asnad-e Enqelab-e Eslami.

Siavoshi, Sussan. 2016. The flock of a shepherd or the sovereign citizen: Ayatollah Montazeri on the role of the people. Journal of South Asian and Middle Eastern Studies XXXIX: 26-46. [CrossRef]

Siavoshi, Sussan. 2017. Montazeri: The Life and thought of Iran's Revolutionary Ayatollah. Cambridge: Cambridge University Press.

Soleimanieh, Mahdi. 2013. Living as a Seminary Student: An Introductory Study of the Sociological Typology of Seminary Students [طلبه زستن: يثوهشى مقدماتى در سنخ شناسى جامعه شناختى زست طلبكى] Tehran: Negah-e Mo'aser.

Sorg, Henry. 2008. The 1988 massacre of political prisoners in Iran: On memory, movements, and debarment. Raisons Politiques 30: 59. [CrossRef]

Soroush, Abdolkarim. 1995a. The Ceiling of livelihood upon the pillar of religion [سقف شربت بر ستون معشت]. Kiyan 5:25-31.

Soroush, Abdulkarim. 1995b. Liberty and clergy [حرنت و روحانتت]. Kiyan 4: 2-11.

Tabatabaeifar, Seyed Mohsen. 2015. Intellectual Trends in the Contemporary Qum Seminary [جروان هاى فكرى در حوزه مع معاصر ق. Tehran: Nashr-e Ney.

Tamadonfar, Mehran. 2001. Islam, law, and political control in contemporary Iran. Journal for the Scientific Study of Religion 40: 205-219. [CrossRef]

Tezcür, Güneş Murat. 2010. Muslim Reformers in Iran and Turkey: The Paradox of Moderation. Austin: University of Texas Press. 